\title{
The analysis of personnel workload on navy hospital ships using the NASA-TLX method
}

\author{
I Made Jiwa Astika *, Avando Bastari and Okol Sri Suharyo \\ Indonesia Naval Technology College, STTAL Surabaya Indonesia.
}

Global Journal of Engineering and Technology Advances, 2021, 07(03), 190-202

Publication history: Received on 16 May 2021; revised on 19 June 2021; accepted on 22 June 2021

Article DOI: https://doi.org/10.30574/gjeta.2021.7.3.0091

\begin{abstract}
Navy Ships A is a Republic of Indonesia Ship type LPD (Landing Platform Dock) which has the main task and additional duties as a Naval Hospital Auxiliary Ship. In their daily life, Navy Ships A carries out maritime security operations to maintain the sovereignty of the Republic of Indonesia, as well as carry out humanitarian social activities. This makes the workload of Navy Ships A personnel in the high category. And it causes a decrease in productivity and morale of personnel which will result in work accidents and not achieving the main tasks assigned to Navy Ships A. This study aims to calculate the workload of Navy Ships A personnel using the NASA TLX (Task Load Index) method under conditions the current number of personnel. This research is expected to be able to calculate the workload of Navy Ships A personnel with the condition that the proper Personnel Composition List (DSP) has not been fulfilled. As well as being able to provide workload calculations according to the number of existing DSPs, so that they can provide recommendations for the right solution to the problem of high workload experienced by Navy Ships A personnel.
\end{abstract}

Keywords: Personnel workload; Navy Hospital Ships A; NASA TLX Method

\section{Introduction}

Article 9 of the Indonesia Force Law no. 34 of 2004 states that the task of the Navy in the field of defense is to enforce the law and maintain security in the marine area of national jurisdiction following the provisions of national law and ratified international law, carry out the tasks of Navy diplomacy in the context of supporting foreign policy policies set by the government, and carry out the duties of the Army force in the development and strength of the marine dimension. The Indonesian Navy has a supporting component in achieving the success of tasks in operational units in peace and critical/war times, where this is an integral part of the strength of the Integrated Fleet Weapon System. Part of the components incorporated in the SSAT is the Base, Navy Ships, Aircraft, and Marines.

Navy Ships A was designated as Warships of the Republic of Indonesia on September 17, 2007, which are members of the ranks of warships under the Indonesian Armada II Command, under the Auxiliary Ship Unit. Apart from being a battleship that has the main task of being a ship capable of projecting land power through the sea, this ship also functions for humanitarian operations and natural disaster management. So that indirectly, in addition to its basic function as a warship patrolling to maintain sovereignty, the ship is also appointed to carry out humanitarian missions as well as natural disaster management.

Navy Ships A has a mandate as a Hospital Auxiliary Ship as stated in the Letter of Navy Chief No. Kep/1275/VIII/2012 concerning the position of two types of Navy Ships A produced by Daesun South Korea. Consideration of Navy Ships A as a hospital auxiliary ship because it has several facilities that other warships do not have.

\footnotetext{
${ }^{*}$ Corresponding author: I Made Jiwa Astika

Indonesia Naval Technology College, STTAL Surabaya Indonesia.

Copyright (C) 2021 Author(s) retain the copyright of this article. This article is published under the terms of the Creative Commons Attribution Liscense 4.0.
} 
In meeting the need to carry out social activities, Navy Ships A has a poly room, operating room, laboratory room, treatment room, pharmacy room, and is also equipped with 1 elevator. Navy Ships A also has a Helly Deck Party, which is a deck for 2 helicopters to land on and capable of loading 3 helicopters with one helicopter in the Helly Hangar. This loading capacity, and supported by Heli landing lights along the deck to support medical evacuation activities.

In addition to the rooms used for social activities that can accommodate hundreds of people, there are also special decks for transport vehicles and combat vehicles. The decks are the Tank Deck and Car Deck. As the name implies, the Tank Deck and Car Deck are special decks for loading tanks (combat vehicles), tactical vehicles, and non-combat vehicles to support social activities carried out.

Based on the description above, Navy Ships A is considered to have had the requirements to become a Hospital Auxiliary Ship which in its implementation is supported by crew members who have professionalism as marine soldiers and have additional competence as a requirement in carrying out hospital functions. In this research, the workload is intended only for personnel with the rank of a non-commissioned officer and enlisted. This is because personnel with the rank of a non-commissioned officer and enlisted have the longest tenure in Navy Ships A

Under normal conditions, the activities of Navy Ships A personnel are the same as those of other Navy Ships A, namely carrying out marine guard services when the ship carries out patrols, as well as carrying out daily administrative activities and land guarding when the ship is docked. However, the condition with a heavier load is when the ship is carrying out a voyage. This is because the personnel by members of both the NCO and the enlisted must carry out the duty of duty within one day (24 hours). In addition, they still have to carry out ship administration activities during working hours from 08.00 to 16.00 time.

Table 1 describes and provides an overview of the activities carried out by Navy Ships A personnel when carrying out activities during the voyage. When carrying out normal sea operations, Navy Ships A personnel have also been under pressure in the form of a large working area. With a length of 122 meters and a width of 22 meters with 6 decks, Navy Ships A personnel practically have to work extra in terms of maintenance, security, as well as equipment and weapon operators. The workload of Navy Ships A soldiers will increase if, during the implementation of social service activities, it is certain that there is a load of VVIP personnel who must get maximum service. However, in the daily activities of soldiers as operators of equipment and Arms, as well as maintenance and security of work areas, they must still be carried out properly.

\section{Material and methods}

\subsection{Workload Concept}

The workload experienced by a worker can be in the form of physical, mental, and psychological burdens arising from the work environment. The workload is designed according to the abilities and limitations of both physical and mental workers. Workload describes the interaction between an operator performing a task and the task itself. In other words, the term workload describes the difference between the capacities of a human information processing system. Henry R. Jex defines mental workload as "the operator's evaluation of the attentional load margin (between their motivated capacity and the current task demands) while achieving adequate task performance in a mission-relevant context" (Hancock, 1988).

\subsection{NASA TLX Methods}

NASA - Task Load Index (NASA-TLX) is a subjective measurement method to determine the mental workload of workers in doing work. The NASA TLX method was developed by Sandra G. from the NASA-Ames research center and Lowell E. Staveland from San Jose state university in 1981. The NASA - Task Load Index is a multi-dimensional rating procedure, which divides the workload based on an average loading of six (6) subscale, namely:

\subsubsection{Mental Needs}

How much mental and perceptual activity is required (e.g. thinking, deciding, counting, memorizing, seeing, and searching), whether the task is simple or complex, easy or difficult.

\subsubsection{Physical Needs}

How much physical activity is required (e.g. pushing, pulling, twisting, controlling, and activating) 


\subsubsection{Time Requirement}

How stressed are you because of the time limit given to do the task, whether your work speed is low or high?

\subsubsection{Performance}

How successful were you in achieving the work goals set in the experiment? Are you satisfied with the work you have produced?

\subsubsection{Effort}

How hard you have to work (physically and mentally) to achieve the level of performance you have achieved.

\subsubsection{Stress Level}

How distracted, bored, annoying, or stressed you are while doing the task.

By measuring these dimensions, it will be known the magnitude of the mental workload of the soldiers serving in Navy Ships A so that it is expected to reduce stress levels when carrying out operational tasks. In essence, the so-called mental workload according to NASA TLX is the "overall workload". So the overall workload includes mental workload as well as physical workload.

Hancock and Meshkati (1988) describe several developments of the NASA TLX method, including:

- Conceptual framework. Workload arises from the interaction between task and job requirements, working conditions, behavior, and perceptions of workers (technicians). The purpose of the conceptual framework is to avoid variables that are not related to subjective workload. In the conceptual framework, the different sources and things that can change the workload are enumerated and linked.

- Information Obtained from Subjective Ratings. Subjective ratings are the most suitable method for measuring mental workload and provide indicators that are generally the most valid and sensitive. Subjective rating is the only method that provides information about the subjective task of workers or technicians and incorporates the influence of workload contributors.

- Making Workload Rating Scale

- Choose the most appropriate set of subscales.

- Determine to combine these subscales to obtain a workload value that is sensitive to sources and a definition of workload that differs both between tasks and among raters.

○ Determine the best procedure to get the best score

- Subscale Selection

There are three subscales in the study, namely the scale related to tasks and the scale related to behavior (physical effort, mental effort, and performance), the scale related to the subject (frustration, stress, and fatigue). The sub-scales written by Hart and Staveland (1981) include:

- Task-related scale. The ratings assigned to task difficulty provide direct information on the subject's perceived needs as differentiated by the task. Time pressure is expressed as a major factor in the definition and model of most operational workloads, quantified by comparing the time required for a series of tasks in an experiment.

- Scale related to behavior. The physical effort factor manipulates the experiment with the physical need factor as the main work component. The experimental results show that the physical effort factor has a high correlation but does not provide a significant contribution to the overall workload. The mental effort factor is an important contributor to the workload at a time when the number of operational tasks increases as worker responsibilities shift from direct physical control to supervision. Mental effort rating was correlated with overall workload rating in each experimental category and was the second most highly correlated factor with the overall workload.

- Scale related to the subject. Frustration is the third most relevant workload. Frustration ratings correlated with overall workload ratings significantly across all experimental categories. The stress rating represents the manipulation that affects the overall workload rating and is the most independent scale. 
Hancock and Meshkati (1988) also describe the steps in measuring mental workload using the NASA TLX method, namely:

Explanation of mental load indicators to be measured.

In the weighting section, respondents are asked to circle one of the two indicators that are felt to be more dominant in causing mental workloads for certain jobs. The NASA TLX questionnaire given is in the form of pairwise comparisons consisting of 15 pairwise comparisons. From this questionnaire, the tally of each indicator that is felt to be the most influential is calculated. This tally number will then be a weight for each mental load indicator.

- Rating. In this section, respondents were asked to rate the six indicators of mental load. The rating given is subjective depending on the mental burden felt by the respondent. To get the NASA TLX mental load score, the weights and ratings for each indicator are multiplied and then added and divided by 15 (the number of pairwise comparisons).

- $\quad$ Calculate product value. It is obtained by multiplying the rating by the factor weight for each descriptor. This results in 6 product values for 6 indicators (MD, PD, TD, CE, FR, EF).

Product $=$ rating $x$ weight factor

- $\quad$ Calculating Weighted Workload (WWL). Obtained by adding up the six product values. $W W L=$ product

- $\quad$ Calculate the average WWL. Obtained by dividing WWL by the total weight Score $=$ (weight $x$ rating $)$

- Score Interpretation.

O Based on the division of the workload scale according to NASA TLX, the workload can be divided into several criteria, among others, values 0-20 are in the very low workload category, 21-40 are low workload categories, 41-60 moderate workloads, 61-80 workloads. high workload and the last 81-100 fall into the category of very high workload.

\section{The Research Methods}

This research activity was carried out from May to October 2020 with an emphasis on ship operations from 2013 to 2020. This research was conducted on an operational unit at the Navy Ships A level which carries out the main task of upholding sovereignty and maintaining territorial security at sea. The activities carried out aim to study and analyze the problems being faced. In addition, look for information related to references from the literature and the results of existing research on mental workload analysis. In conducting research, it is necessary to set a goal for the research. While the benefits of research are the results that can be taken from this research so that the resulting output can be useful for all parties concerned.

\section{Data Sources, Subjects, and Research Objects}

This research was conducted from various sources to enrich the desired study results. Seek references from the results and existing research literature on mental workload analysis, and carry out discussions with people who have experience in the field. The sources used in this study are textbooks, journals, seminar papers, and articles from the internet, as well as research in the form of final assignments, previous theses and supplemented by Navy Ships A data.

The subjects of this research are members of the rank of non-commissioned officers and enlisted men who serve in Navy Ships A, and the object of research is the workload of personnel serving in Navy Ships A.

\section{Data collection technique}

There are several methods of data collection techniques carried out in research activities to obtain quantitative data and information from existing respondents following the scope of research. Some of the techniques used include:

- Interview.

- Observation.

- Questionnaires. 


\subsection{Data Collection Instruments}

The instruments used in this research are as follows:

- Data Navy Ships A.

- $\quad$ NASA TLX mental load indicator questionnaire.

- NASA TLX Software

\subsection{Data analysis technique}

Data processing is carried out using the NASA-TLX method, where the input is a questionnaire that has been given to each soldier who works according to his field of duty to find out the workload experienced by each Personnel in carrying out daily activities in Navy Ships A when carrying out operational duties shipping and ships are at the base. The steps for measuring mental workload using NASA-TLX are as follows:

- The weighting of the results of the questionnaire.

- Rating.

- Calculation of WWL value.

- Categorization of workload assessment

The next step is to analyze the results of the data processing. According to NASA TLX, the categorization of workloads can be divided into several criteria, among others, values 0-20 fall into the very low workload category, 21-40 low workload categories, 41-60 moderate workload categories, 61-80 high workloads, and the last 81-100 fall into the very high category.

\subsection{Interview and Questionnaire}

The interview is a procedure used to dig up data orally by carrying out questions and answers with the object of research. In this case, Navy Ships A soldiers who are members of the Department of Operations, Maritime Affairs, Machinery, and Logistics. This activity is carried out to obtain valid and accurate results.

Meanwhile, in designing this questionnaire, it was made based on activities carried out routinely by Navy Ships soldiers under the existing schedule. The form of the questionnaire is made and adjusted for filling. Distribution of Questionnaires NASA TLX mental burden indicator was distributed to respondents who are currently serving on the Hospital Auxiliary Ship.

The determination of the respondent sample is carried out as a whole for members of Navy Ships A with the rank of NCO and Enlisted, which can be seen in Table 1.

Table 1 Number of NCO and Enlisted Navy Ships A

\begin{tabular}{|l|c|c|c|}
\hline \multicolumn{1}{|c|}{ Personnel } & NCO & Enlisted & Amount \\
\hline Operation & 7 & 4 & 11 \\
\hline Marine Arms & 4 & 14 & 18 \\
\hline Machinery & 4 & 13 & 17 \\
\hline Logistics & 8 & 4 & 12 \\
\hline
\end{tabular}

\section{Results and discussion}

The calculation process using the NASA TLX method on all Navy Ships A Soldiers can be seen in Table 2. From the table, it can be seen that the workload of Navy Ships A Soldiers has a high workload with an average number of 69.45. To carry out an appropriate analysis, and obtain an expected solution, it is necessary to sort out the workload analysis according to the existing Department. This is related to the duties and responsibilities of each Personnel that are not the same as each other, as stated in the Technical Guidelines for the Job Description of Navy Ships A. It is hoped that the solution obtained can be a way out to overcome the problem of the high workload of soldiers. 
The results obtained through the total calculation will be re-sorted through each existing Department, according to the work environment and equipment or weapon operators according to the duties and responsibilities of each Personnel in the Department. A soldier who is a member of the Operations Department will certainly be different from the Maritime Arms Department Personnel, the Machinery Department Personnel and the Logistics Department Personnel regarding the duties and responsibilities carried out. Therefore, it is necessary to sort out the workload indicators in each department to find out the causes of excessive workloads that can lead to a decrease in morale and personnel performance. Because this can affect the security and safety of the personnel themselves as well as the safety and security of the ship during shipping operations and when the ship is docked at the base. The comparison of the six indicators after being average can be seen in Table 2 .

Table 2 Average Results of Respondents' Workload Values for Each Department

\begin{tabular}{|l|c|c|c|c|c|c|c|}
\hline \multicolumn{1}{|c|}{ DEPT } & $\boldsymbol{\Sigma}$ MD & $\boldsymbol{\Sigma}$ PD & $\boldsymbol{\Sigma}$ TD & $\boldsymbol{\Sigma}$ OP & $\boldsymbol{\Sigma}$ EF & $\boldsymbol{\Sigma}$ FL & AVG WWL \\
\hline DEPT.OPS & 285,5 & 144,5 & 56,4 & 144,5 & 179,1 & 260,9 & 71,39 \\
\hline DEPT.MARINE ARM & 91,7 & 269,4 & 143,3 & 102,8 & 262,8 & 166,1 & 69,07 \\
\hline DEPT.MACHINERY & 136,5 & 203,5 & 210 & 258,2 & 76,5 & 141,8 & 68,43 \\
\hline DEPT.LOGISTICS & 223,8 & 81,3 & 288,8 & 221,3 & 148,1 & 81,3 & 69,63 \\
\hline
\end{tabular}

The results of the recapitulation of NASA TLX calculations in each Department are as follows:

- Operations Department. From the recapitulation table of NASA TLX calculations, Navy Ships A Operations Department personnel have an average workload value of 71.39. This gives an understanding that the workload of Navy Ships A Operations Department Personnel has a High workload level category.

- Marine Arms Department. From the recapitulation table, NAVY SHIPSA's Armed and Maritime Department personnel have a high workload category of 69.07 even though it is 2.32 lower than the average value of the Operations Department Personnel's workload.

- Machinery Department. For the results of the recapitulation table of NASA TLX Machine Department Personnel calculations, Navy Ships A has a high workload level category of 68.43. The score is 2.96 lower than the average value of the Operations Department and 0.64 lower than the average value of the Marine Arms Department

- Logistics Department. From the results of the recapitulation table of NASA TLX calculations, Navy Ships A Logistics Department Personnel has an average workload value of 69.63. This shows that the Logistics Department Personnel has a high workload when carrying out Service in Navy Ships A.

\subsection{Analysis of Workload Results of Each Department}

Based on the data that has been processed previously, if it is necessary to carry out an analysis per Department to provide information about the problems and constraints faced in each Department:

\subsubsection{Analysis of the Workload of Operations Department}

The results of data processing of Operations Department personnel who serve as bridge guards, navigation equipment operators when the ship sails, as well as radio operators both UHV, VHF, and HF during the ship's base or carrying out operations, have an average final result of 70.91 where this value is included in High category. By focusing on the Mental Demand load indicator factor with an average mental load of 273.64 it gives an understanding that the Operations Department has the highest mental load value compared to other Departments. The workload indicator that occupies the second position that affects the workload of the Operations Department Personnel is the Frustration Level or the level of stress. This was triggered by the work demands of the Operations Department which required work with almost no errors because the work demands greatly affected the achievement of the main tasks and additional tasks.

The next indicator that occupies the third position is Effort (EF). Effort or Effort ranks third because in carrying out their duties, personnel often encounter conditions to carry out things outside the procedure. Because the existing equipment is equipment that is no longer new and in daily operations, it must be carried out under existing procedures and procedures. The fourth position is Physical Demand (PD), which shows that in carrying out daily activities, Operations 
Department personnel also require excellent physical readiness. As a small example, physical activities are carried out when personnel carries out cleaning and tidying of spaces which are the responsibility of the Operations Department.

The next indicator, which both occupy the fourth position is Performance / Own Performance (OP). Performance is related to job satisfaction. Considering that the output of the work carried out by the Operations Department Personnel is very important and confidential, performance indicators are very necessary for carrying out daily activities. Temporal Demand (TD) or Time Needs as the fifth or last indicator gives an illustration that even when receiving news from Communications people, and Navigation equipment operators during the voyage. As well as activities outside of ship operations, the Operations Department personnel have been able to carry out their duties properly. This is related to their knowledge which spends more time carrying out learning either through courses or schools.

\subsubsection{Analysis of the Workload of the Marine Arms Department}

The calculations show that the Department of Marine Arms has a very large burden on the physical workload. This result is the highest calculation result among the three departments carrying out the research. The high physical workload is influenced by the size of the work area that is the responsibility of the Department of Arms and Maritime Affairs.

The next indicator that occupies the second position is Effort (EF). Effort or Effort ranks second because in carrying out their duties, personnel often encounter conditions to carry out things beyond their capabilities. For example, the personnel of the Department of Arms and Maritime Affairs have to work extra when there are Social Service activities and Protocol activities where they must prepare the ship's tidiness, both paint and rust removal on the ship's hull. And also because of inadequate equipment due to a limited budget, it is not uncommon for personnel to use equipment that is no longer suitable for use. The position of the three workload indicators that affect the workload of the Maritime Arms Department personnel falls on the level of stress. This was triggered by the work demands of the Department of Arms and Maritime Affairs which required more work because the results of the work of the Department of Maritime Arms were the first impression that military and non-military officials would see.

In the fourth position is the need for time/Temporal Demand (TD). The time referred to here is the working time that must be taken during carrying out the activity. Time analysis is of course directly proportional to the area of the work area. The wider the area of work that is the responsibility of the Department of Arms and Maritime Affairs, the longer it will take to complete the work.

The next indicator is Performance. The performance or job satisfaction level of the Department of Arms and Maritime Affairs is low. This is because the results of the work carried out are very large so that the target for completion of work for the personnel of the Arms and Maritime Department is time. The sooner a job is finished, the faster it is for Personnel to rest. So that the quality of work is neglected, and the level of satisfaction with the work done is low. The lowest indicator in the Maritime Arms Department is the Mental Factor. This, of course, goes back to the consequences or effects on the results of the work, because it will have fatal consequences and have an impact on the organization and the person concerned. Therefore, when carrying out these activities, the Department of Arms and Maritime Affairs must still mentally prepare for the results of the work that has been done.

From the brief review above, it makes perfect sense that the total workload received by the Arms and Maritime Department has the highest workload compared to the Operations Department, the Machinery Department, and the Logistics Department. So it is hoped that there will be a solution from the results of this research, considering the duties, responsibilities, and work risks that must be faced.

\subsubsection{Analysis of Workload Machine Department}

The Engineering Department is the Department responsible for maintaining Navy Ships A buildings and machinery in carrying out the daily main tasks of Navy Ships A. As the Department in charge of maintaining Navy Ships A buildings and machinery, it can be said that the activities carried out by the Machinery Department are indoors. These activities include maintenance and supervision of the main engine, auxiliary machinery, and the KRI electrical system.

The highest indicator is Own Performance. This shows that the performance needs of the Mechanical Department personnel while carrying out tasks under the work given is still relatively low. With the Own Performance indicator factor being in the first position, it shows a high load of the Machinery Department Personnel Performance. This is due to the personnel of many factors, such as the high and low demands demanded by superiors in completing work to subordinate personnel which can burden the performance of their personnel during work. The second and third indicators have almost the same value, namely indicators of Time needs and Physical needs. This means that the time needs are balanced with the physical needs that are carried out. Where the work required is relatively fast and balanced 
with quite heavy physical activities. The fourth indicator is the level of stress. This was triggered by the work demands of the Machinery Department which required working in a place with high noise and hot air temperatures. This, of course, reduces the convenience of the Machinery Department personnel. In fifth place is the Mental Demand Indicator. This shows that the mental needs of the Mechanical Department personnel are quite high. This can not be separated from or influenced by the four previous indicator factors which cause the indicator factor for Mental needs of the Mechanical Department personnel to be quite high.

While the last rank is the indicator of Effort or level of effort. This shows the level of effort required by the personnel of the Machinery Department is high. For example, if there are sailing activities with civilian passengers. Most civilian passengers do not comply with applicable regulations, one of which is throwing garbage in the toilet. This, of course, creates a blockage in the sewer pipe and must be repaired by the Department of Internal Affairs personnel.

\subsubsection{Analysis of Workload Logistics Department}

The Logistics Department is a Support Department or a supporting Department in carrying out the daily main tasks of Navy Ships A. Until there is a term that, Logic cannot win the battle, but without Logistics, the battle cannot be won. So from the above statement, it is sufficient to explain how important and influential ship logistics is to the achievement of Navy Ships A's tasks.

As the Department in charge of supporting ship activities, almost $80 \%$ of the activities carried out by the Logistics Department are indoors. These activities include administration, publications, responsible for support related to operations, cooking, storage of wet and dry ingredients, and others. While the activities carried out outside the room are only individual, namely some personnel who do have responsibilities under the Navy Ships A working manual such as Payers, PUT (Request To Receive), and others.

The high time requirement is certainly followed by other workload indicators, the longer the work is carried out, the more severe the mental needs and performance of personnel that need to be prepared. This can be seen in Figure 4 which shows the second indicator is held by mental needs and the third indicator is held by performance.

The fifth and sixth indicators have the same value, namely the Performance and Business level indicators, both of which have a weighted value of 81.3. This means that performance is balanced with the level of effort made. And the level of stress which is the fourth indicator also provides an illustration that the level of work effort and the risks faced are quite significant.

\subsection{Analysis of Workload Results Based on Length of Service}

When viewed in terms of the length of service in Navy Ships A, the respondents were divided into 3 categories, namely the length of service in Navy Ships A for 1 year to 5 years, 6 years to 10 years, and 11 years to 15 years. Based on the results of data processing, it is known that personnel who serve between 11 and 15 years have the highest workload value, but it is necessary to carry out an analysis in each workload to provide information about the problems and obstacles faced in each group of the length of service:

\subsubsection{Mental Demand Comparison}

The value of Mental Demand workload for 6-10 years has the highest Mental Demand workload with a value of 187.5. This is because personnel with 6-10 years of service are often given responsibilities by KRI officers.

\subsubsection{Physical Demand Comparison}

The value of the Physical Demand workload of personnel whose length of service is 11-15 years has the highest value of 214. This is called Personnel because the average age of PERSONNEL with a length of service of 11-15 years is older than the other groups of the length of service, which is between 30 to 50 years. . This of course causes the physical workload of 11-15-year-old group to be the highest among other old service groups

\subsubsection{Temporal Demand Comparison}

The value of the Mental Demand workload of personnel with 1-5 years of service has the highest value, namely 198.9. This is because in carrying out their duties, groups of 1-5 years of service, which are generally filled by junior soldiers, are required to complete work earlier than soldiers with 6-10 years of service and personnel with 11-15 years of service. Even personnel with 1-5 years of service often work late at night because on average, personnel with 1-5 years of service are still in Deep Sleep status or unmarried which requires them to sleep on the ship. 
Table 3 Average Workload Value Based on Length of Service

\begin{tabular}{|l|c|c|c|c|c|c|c|}
\hline \multicolumn{1}{|c|}{ LENGHT } & $\boldsymbol{\Sigma}$ MD & $\boldsymbol{\Sigma}$ PD & $\boldsymbol{\Sigma}$ TD & $\boldsymbol{\Sigma} \mathbf{O P}$ & $\boldsymbol{\Sigma}$ EF & $\boldsymbol{\Sigma}$ FL & AVG WWL \\
\hline 1-5 Years & 161,2 & 168,5 & 198,8 & 171,2 & 158,1 & 159,7 & 67,68 \\
\hline 6-10 Years & 187,5 & 158,8 & 186,3 & 199,4 & 170 & 133,8 & 69,04 \\
\hline $11-15$ Years & 175 & 214 & 162 & 186,5 & 177 & 164 & 71,9 \\
\hline
\end{tabular}

\subsubsection{Own Performance Comparison}

The value of the Own Performance workload for 6-10 years has the highest Own Performance workload with a value of 187.5. This gives an understanding that the level of success and job satisfaction of personnel with 6-10 years of service is related to the tasks assigned by the officers.

\subsubsection{Effort Comparison}

The value of the workload Effort of personnel whose length of service is 11-15 years has the highest value of 177 . However, this result is not too far from that of personnel whose length of service is 1-5 years and 6-10 years. From these data, it shows that the level of effort made by personnel in all old categories can be said to be almost the same.

\subsubsection{Frustration Level Comparison}

The stress level value of 11-15 years of service is almost the same as 1-5 years of service. Where personnel with 11-15 years of service have a value of 164 while. This is very possible because personnel with 1-5 years of service are in a transition phase where they are required to quickly adapt to their main duties in the KRI. Meanwhile, personnel with 11-15 years of service are in a saturated phase and have many family problems.

\subsection{Analysis of Workload Results Based on Number of DSP}

Based on the calculation of the final NASA TLX score in each Department, it is known that each Department has a high workload value. In Table 3.1 we can see the condition of the lack of Personnel in each Department. According to Ramadhan (2014) to reduce the workload, it is necessary to propose improvements, namely by adding more workers by dividing the analyzed total workload (WWL) by the expected number of workers.

In this case, it is necessary to carry out a workload analysis in each Department if it has the number of Personnel according to the DSP, to provide information on the workload faced by each Department by dividing the results of the WWL by the number of DSP in each Department. The results of AVG WWL with distribution according to DSP can be seen in Table 4, with the following calculations:

Table 4 Number of Personnel and WWL of Each Department

\begin{tabular}{|l|l|l|l|l|l|l|}
\hline \multirow{2}{*}{ No } & \multirow{2}{*}{ Department } & WWL & Real & AVG WWL & DSP & AVG WWL \\
\cline { 3 - 7 } & & Real & (Pers) & Real & (Pers) & DSP \\
\hline 1 & Operation & 785,33 & 11 & 71,39 & 19 & 41,33 \\
\hline 2 & Marine Arms & 1243,33 & 18 & 69,07 & 30 & 41,44 \\
\hline 3 & Machinery & 1163,33 & 17 & 68,43 & 33 & 35,25 \\
\hline 4 & Logistics & 1114 & 16 & 69,63 & 24 & 46,42 \\
\hline
\end{tabular}

\subsubsection{Operations Department}

The Operations Department with a real number of 11 personnel received a WWL score of 785.33 with an AVG WWL of 71.39 in the high workload category. If analyzed with the number of DSP Operations Department totaling 19 Personnel, the following results were found: 


$$
\begin{aligned}
& =\text { WWL Real Dep Ops/DSP Dep Ops } \\
& =785.33 / 19 \\
& =41.33 \text { (Medium) }
\end{aligned}
$$

\subsubsection{Department of Marine Arms}

The number of real personnel 18 personnel received a WWL value of 1243.33 with an AVG WWL of 69.07 and a high workload category. If analyzed with a total of 30 DSP personnel, the following results were found:

AVG WWL DSP Dep Marine Arms =

= WWL Real Dep Marine Arms/DSP Dep Marine Arms

$$
\begin{aligned}
& =1243.33 / 30 \\
& =41.44 \text { (Medium) }
\end{aligned}
$$

\subsubsection{Department of Machinery}

In the Department of Machinery with a real number of 17 personnel, the WWL score is 1163.33 with AVG WWL 68.43 in the high workload category. If analyzed with the number of DSP of the Machinery Department of 33 Personnel, the following results were found:

$$
\begin{aligned}
& \text { AVG WWL DSP Dep Machinery }= \\
& =\text { WWL Real Dep Machinery /DSP Dep Machinery } \\
& =1163.33 / 33 \\
& =35.25(\text { Low })
\end{aligned}
$$

Due to the results with a low number of DSP, it is necessary to study the number of DSP of the Department of Machinery to have an optimal value or fall into the medium category. The number of DSP that will be assumed is 29 Personnel, then the following results are found:

$$
\begin{aligned}
& \text { AVG WWL DSP Dep Machinery = } \\
& =\text { WWL Real Dep Machinery /DSP for example Dep Machinery } \\
& =1163.33 / 29 \\
& =40.12 \text { (Medium) }
\end{aligned}
$$

\subsubsection{Logistics Department}

In the Logistics Department with 16 real personnel, the WWL score is 1114 with AVG WWL 69.63 in the high workload category. If analyzed with the number of DSP of the Machinery Department of 24 personnel, the following results were found:

$$
\begin{aligned}
& \text { AVG WWL DSP Dep Logistics }= \\
& =\text { WWL Real Dep Logistics/DSP Dep Logistics } \\
& =1114 / 24 \\
& =46.42 \text { (Medium) }
\end{aligned}
$$




\section{Conclusion}

Based on the data collection, processing and calculation carried out to calculate the workload of Navy Ships A personnel, the following conclusions can be obtained:

\subsection{The average workload value of data processing with NASA-TLX for each Department is:}

- $\quad$ Operations Department 71.39.

- Marine Arms Department 69.07.

- Department of Machinery 68.43.

- Logistics Department 69.63.

\subsection{While the average workload for each category of Service Length is as follows:}

- $\quad$ The length of service from 1 to 5 years is 67.82 .

- $\quad$ Length of service from 6 to 10 years is 69.04 .

- $\quad$ The length of service from 11 to 15 years is 71.9 .

\subsection{The dominant indicators in each Department are as follows:}

- $\quad$ Operations Department with dominant indicators of Mental Demand and Frustration Level.

- Arms and Maritime Department with dominant indicators of Physical Demand and Effort.

- Machinery Department with the dominant indicator of Own Performance.

- Logistics Department with dominant indicator Temporal Demand.

\subsection{While the dominant indicators for each category of Service Length are as follows:}

- Length of service from 1 to 5 years with the dominant indicator of Temporal Demand.

- Length of service 6 to 10 years with dominant indicators of Mental Demand and Own Performance.

- Length of service 11 to 15 years with dominant indicators of Physical Demand, Effort, and Frustration Level.

\subsection{Based on the number of DSP Navy Ships A the value of workload in each Department is as follows:}

- Operations Department with a DSP of 19 personnel has a score of 41.39 and is in the medium category.

- The Department of Arms and Maritime Affairs with a DSP of 30 personnel has a value of 41.44 and is included in the medium category.

- Department of Machinery with 33 Personnel DSP has a score of 35.25 and is included in the low category, but with a reduction in the number of DSP to 29 Personnel the score becomes 40.12 and is included in the medium category.

- The Logistics Department with 24 Personnel DSP has a score of 46.42 and is included in the medium category.

\section{Compliance with ethical standards}

\section{Acknowledgments}

The authors greatly acknowledge the support from Indonesia Naval Technology College STTAL Surabaya for providing the necessary resources to carry out this research work. The authors are also grateful to the anonymous reviewers and journal editorial board for their many insightful comments, which have significantly improved this article.

\section{Disclosure of conflict of interest}

The authors declare no conflict of interest. 


\section{References}

[1] Arsi RM. Analisa Beban kerja untuk Menentukan Jumlah Optimal Karyawan dan Pemetaan Kompetensi Karyawan Berdasar pada Job Description. Surabaya: Jurnal Teknik ITS. 2012.

[2] Bandono A, Bastari A, Suharyo OS. Effectiveness Naval Collaboration Flexible Learning (NCFL) Model in Increasing Learning Outcomes The Indonesian Naval Technology College. International Journal of Progressive Sciences and Technologies. 2020; 23(2): 434-442.

[3] Bandono A. 12. Jurnal The Application Model of Naval Collaboration FlexibleLearning (NCFL) in the Indonesian Naval Technology College: A Case Study. International Journal of Progressive Sciences and Technologies (IJPSAT). $2020 ; 23(2): 498-505$.

[4] Bandono A, Suharyo OS. Development of Computer Media For Interactive Learning Course Pump And Compressors Application In Students of D3 Mechanical Engineering Program. International Journal of Progressive Sciences and Technologies. 2021; 24(1): 323-336.

[5] Bastari A, Suharyo OS. Analysis of The Implementation of Occupational Safety Program Efforts to Improve Work Productivity With Fault Tree Analysis Approach. International Journal of Progressive Sciences and Technologies. 2020; 23(2): 728-733.

[6] Bastari A, Bandono A, Suharyo OS. The development strategy of smart campus for improving excellent navy human resources. Global Journal of Engineering and Technology Advances. 2021; 6(2): 033-043.

[7] Bastari A, Kusuma E, Suharyo OS, Hartoko P. OFFENSIVE AND DEFENSIVE CAPABILITY COMPARISION BETWEEN IVER HUITFELDT CLASS AND PKR105 CLASS BASED ON SALVO MODEL. JOURNAL ASRO-STTALINTERNATIONAL JOURNAL. 2020; 11(04): 72-76.

[8] Budiman J. Analisa Beban Kerja Operator Air Traffic Control Bandara XYZ Dengan Menggunakan Metode NasaTLX. Jakarta. 2013.

[9] Depkes RI. Pedoman Pembinaan Kesehatan Usia Lanjut Bagi Petugas Kesehatan. Jakarta. 2003.

[10] Gempur Santoso. Manajemen Keselamatan dan Kesehatan Kerja. Jakarta: Cetakan Pertama.Prestasi Pustaka. 2004.

[11] Gibson, Ivancevich, Donnelly. Organisasi, Prilaku, Struktur, Proses. Jakarta: Bina Rupa Aksara. 1996.

[12] Hidayat TF. Pengukuran Beban Kerja Perawat Menggunakan Metode NASA TLX di Rumah Sakit XYZ. 2013.

[13] Hima AF, Umami MK. Evaluasi Beban Kerja Operator Mesin pada Departemen Log and Veeneer Preparation di PT. XYZ. Jurnal Teknik dan Manajemen Industri Universitas Trunojoyo. Madura. 2011.

[14] Hancock PA, Meshkati N. Human Mental Workload. Elsevier. 1988.

[15] Handoko T. Hani. Manajemen dan Sumber Daya Manusia. Yogyakarta: Penerbit Liberty. 1997.

[16] Hasibuan, Malayu. Manajemen Sumber Daya Manusia. Jakarta: Bumi Aksara. 2006.

[17] Handoyo, Seger. Stress Pada Masyarakat Surabaya. Jurnal Ibsan. Surabaya: Media Psikologi. 2001.

[18] Indra Petrus. Analisa Beban Kerja PERSONEL NAVY SHIPSDewaruci Metode Subjective Workload Assessment Technique (SWAT). Surabaya: Teknik Manajemen Industri STTAL. 2013.

[19] Miranti Siti Astuty, Caecillia SW, Yuniar. Tingkat Beban Kerja Mental Masinis berdasarkan NASA-TLX (Task Load Index) di PT. KAI Daop. II. Bandung. 2012.

[20] Nugroho SH, Suharyo OS, Bandono A. The Assessment of Management Effectiveness Program on Organizational Performance Satisfaction. Assessment. 2020; 29(4): 4730-4741.

[21] Suharyo OS, Bastari A, Ariyoko HB, Agustian I. The Sustainability Naval Base Model Using System Dynamic Methods. 2019.

[22] Suharyo OS, Bastari A, Ariyoko HB, Agustian I. The Sustainability Naval Base Model Using System Dynamic Methods. 2019.

[23] Suharyo OS, Manfaat D, Armono HD. Establishing the location of naval base using fuzzy MCDM and covering technique methods: A Case Study. International Journal of Operations and Quantitative Management, IJOQM. 2017; 23(1): 61-87. 
[24] Pulat BM. Fundamental of Industrial Ergonomic. NJ: Prentice Hall Inc. 1992.

[25] Ramadhan R. Analisis Beban Kerja Mental Dengan Menggunakan Work Sampling dan NASA-TASK LOAD INDEX Untuk Menentukan Jumlah Operator. Jurnal Teknik Industri Malang: Universitas Brawijaya. 2014.

[26] Risma A. Analisis Beban Kerja Mental Dengan Metoda NASA-TASK LOAD INDEX. Jurnal Teknik Industri Yogyakarta: Institut Sains \& Teknologi AKPRIND. 2010.

[27] Ribuantoro Andy. Analisa beban kerja prajurit NAVY SHIPSSurabaya-591 sebagai kapal markas TNI AL menggunakan metode NASA TLX (Task Load Index). Surabaya : Teknik Manajemen Industri STTAL. 2016.

[28] Sehnert Keith W. Mengendalikan Stress Dalam Rumah Tangga dan Pekerjaan. Bandung: Yayasan Kalam Hidup. 1981.

[29] Steven, Robbins. Prilaku Organisasi, Jilid 1 Edisi 8. Jakarta: PT Prenhalindo. 2001.

[30] Sutalaksana IZ. Teknik Perancangan Sistem Kerja. Edisi Kedua. Bandung: Penerbit ITB. 1979.

[31] Wignjosoebroto S. Ergonomi, Studi Gerak dan Waktu, Edisi Pertama. P.T. Guna Widya. Jakarta. 2003.

[32] Wignjosoebroto S. Ergonomi, Studi Gerak dan Waktu, P.T. Guna Widya. Surabaya. 2008.

[33] Yerkes R, Dodson JD. The Relationship of Stimulus to Rapidity of Habit Formation. Journal of Comparative Neurological Psychology. 1908.

[34] Yoder, Dale, et. Al. Handbook of Personnel Management and Labour Relation, Mc Graw Hill Book Company. Inc, New York, Toronto, London. 1958. 